\title{
В ПОИСКАХ ОБЪЯСНЕНИЯ ЛАНДШАФТНО-ЭКОЛОГИЧЕСКИХ ФЕНОМЕНОВ И ЗАКОНОМЕРНОСТЕЙ ПРОСТРАНСТВЕННО-ВРЕМЕННОЙ ОРГАНИЗАЦИИ ГЕОСИСТЕМ. К 80-ЛЕТИЮ СО ДНЯ РОЖДЕНИЯ ЮРИЯ ГЕОРГИЕВИЧА ПУЗАЧЕНКО
}

\author{
(С) 2020 г. Ю.П. Баденков ${ }^{a}$, А. В. Дроздов ${ }^{a, *}$, А. Н. Кренке ${ }^{a}$, А. Ю. Пузаченко ${ }^{a}$, \\ М. Ю. Пузаченко ${ }^{a}$, Р. Б. Сандлерский ${ }^{b}$ \\ ${ }^{a}$ Институт географии РАН, Москва, Россия \\ ${ }^{b}$ Институт проблем эволюции и экологии РАН, Москва, Россия \\ *e-mail:drozdov2009@gmail.com \\ Поступила в редакцию 03.12.2019 г. \\ После доработки 05.12.2019 г. \\ Принята к публикации 06.12.2019 г.
}

DOI: $10.31857 / \mathrm{S} 2587556620010197$

Начало 1960-х годов. Замоскворечье. На втором этаже старого двухэтажного дома в Мароновском переулке по адресу д. 2, кв. 10, в небольшой комнате за столом, заваленным огромными таблицами и книгами, Юра Пузаченко щелкает клавишами счетной машинки "Быстрица". Рядом в старинном подстаканнике стакан крепкого черного чая. Комнаты этажа выстроены замкнутой анфиладой. Неслышно появляется Юрина бабушка и стакан обновляет. Друзья, как и Юра, недавно закончившие географический факультет МГУ, слушают его рассказ о коэффициентах передачи информации между компонентами природных комплексов, об информационно-логическом анализе и о результатах его применения. Анализу подвергнут большой массив собранного Юрой полевого материала. Сформулирована гипотеза о независимости элементов комплекса внутри него как целого.

Этот эпизод содержит характерные черты творчества Юрия Георгиевича - всегда искать и находить новый эмпирический материал, искать и разрабатывать новые адекватные методы его получения и анализа, понимать и объяснять его результаты в контексте общенаучных представлений. Менялись объекты и предмет исследования, менялись способы исследования, но неизменным оставалось стремление Юрия Георгиевича к постижению механизмов самоуправления, саморазвития природы и в первую очередь живого вещества Планеты. Неизменной была позиция - не следовать научной моде и конъюнктуре ради жизненного успеха.

\footnotetext{
${ }^{1}$ Юрий Георгиевич родился 2 февраля 1940 г. в Москве. Скончался в Москве 10 ноября 2018 г.
}

Юрий Георгиевич был убежден в том, что в современном мире "научное знание и возникшие на его основе технологии получили небывалые темпы развития и его пределов пока не видно, а возможно их и не существует". Всем его исследованиям и публикациям были присущи характерный авторский стиль, особенности изложения с отчетливым выделением связей между частным и общим. Тематическое, предметное, региональное многообразие публикаций Юрия Георгиевича огромно. Объекты его исследований охватывают всю иерархию организации жизни - от индивидуумов и популяций до биосферы.

Феномен размерной иерархии географических систем был одним из основных постоянных объектов исследований Юрия Георгиевича на протяжении всей жизни. Объяснение этого феномена обретает законченность через трактовку геосистемной иерархии как проявления и следствия механизмов самоорганизации на основе взаимодействий элементов природной системы в процессе ее эволюции. В целом с этих же позиций Юрий Георгиевич рассматривал феномены разнообразия в природе и относительной устойчивости пространственно-временной неоднородности живого вещества в биосфере.

Обладая очень широким научным кругозором, основу для моделирования объектов исследования и развития теоретической географии и экологии Юрий Георгиевич находил в смежных областях естествознания, прежде всего в физике и математике, там, где соответствующие модели разработаны гораздо лучше, чем в географии и биологии.

Результаты своих теоретических исследований Юрий Георгиевич реализовывал на практике. Он внес большой вклад в организацию и научно- 
идеологическое обоснование долговременных эколого-географических исследований (мониторинга), в первую очередь на особо охраняемых природных территориях СССР, а затем и России, в обоснование концепций устойчивого развития и экосистемных услуг.

Научные мировоззрение и интересы географанатуралиста в очень большой степени определяются особенностями того региона или типа среды, в которых он формировался как исследователь и проводил многолетние работы. Верно и обратное - сложившийся географ, продолжительное время работающий в новой для него природной среде, вносит новации в задачи и методы ее изучения.

Почти десять лет, проведенных Юрием Георгиевичем на Дальнем Востоке (1972-1982), стали яркой главой его насыщенной научной жизни, обогатили ее пониманием структуры и динамики природных систем бореального муссонного региона. Эти годы существенно повлияли и на жизнь научного сообщества региона. Юрий Георгиевич был одним из отцов-основателей Тихоокеанского института географии ДВО РАН. Основал в поселке Хрустальный биогеоценологический стационар, где изучались причины усыхания ельников Сихотэ-Алиня и разрабатывалась методология прогноза этого явления.

Десятки, если не сотни, студентов и молодых ученых Владивостока и Москвы прошли Школу Пузаченко при работе на стационаре, оборудованном многочисленными приборами и датчиками. Это был его стиль работы - высокотехнологичный и интерактивный, когда полученная информация обрабатывалась в режиме on line, с использованием компьютеров (1970-е) и, позднее, ГИС-технологий. В Дальневосточном государственном университете Ю.Г. Пузаченко читал спецкурс “Математические методы в географии”. По воспоминаниям его бывших студентов, читал вдохновенно, иногда по несколько часов кряду.

Опыт стационарных исследований в Приморье очень пригодился и в двух экспедициях на научном судне "Каллисто" на острова и атоллы юго-западной Пацифики (1976 и 1980 гг.). Экспедиции выполнялись в рамках Программы ЮНЕСКО “Человек и Биосфера" (МАБ), проект № 7 “Экосистемы малых островов и их рациональное использование”. Юрий Георгиевич был научным руководителем этих экспедиций, в их организации проявились его талант и мудрость, позволившие объединить идеологию маститых советских и зарубежных ученых с энергией и энтузиазмом молодого поколения дальневосточных коллег.

Это был счастливый период сотворчества науки и государства, который принес замечательные результаты и, самое главное, позволил в полной мере раскрыться талантам настоящих ученых, к которым безусловно принадлежал Юрий Георгиевич Пузаченко.
Глубокие российские социально-экономические изменения 1990-х годов затронули и российскую науку. Кардинально сократилось финансирование, исчезли многие источники информации. В этих условиях последние 30 лет Юрий Георгиевич активно развивал исследования в южной тайге Европейской территории России. Их базой служил Центрально-Лесной государственный природный биосферный заповедник в Тверской области. Там под его руководством силами студентов старших курсов и аспирантов географического факультета МГУ были развернуты многолетние классические ландшафтно-экологические полевые наблюдения. Но Юрий Георгиевич не был бы самим собой, если бы не сумел наладить также и уникальные для российских условий экспериментальные исследования энергогазообмена таежных биогеоценозов. При участии зарубежных коллег и давних соратников по работам в Приморье в 1998 г. в заповеднике была установлена вышка для микроклиматических наблюдений по методу Eddy Covariance (метод микровихревых пульсаций).

Материалы всех полевых наблюдений соотносились с данными мультиспектральных дистанционных наблюдений (Д33). С начала 2000-х годов эти данные стали доступны для компьютерной обработки. В дистанционной информации Юрий Георгиевич видел не просто изображения земной поверхности, а уникальную измерительную систему, дающую информацию о свойствах ландшафтов, состоянии их компонентов и протекающих в них энергетических процессах. На ее основе Юрием Георгиевичем и его сотрудниками была разработана методика оценки термодинамических параметров преобразования солнечной энергии ландшафтным покровом. Так были созданы принципиально новые возможности для анализа пространственно-временно́й организации, функционирования и динамики геосистем.

На протяжении всей научной жизни Юрий Георгиевич передавал свои знания о природе ученикам. Он был непростым и очень требовательным учителем, у которого могли по-настоящему учиться только такие же, как и он сам, сильные и самостоятельно мыслящие молодые исследователи. Его ученики, без сомнения, будут продолжать начатые вместе с учителем исследования и сохранят традиции, сложившиеся в созданном Юрием Георгиевичем коллективе единомышленников.

Работа крупного ученого-естествоиспытателя природы, каким был Юрий Георгиевич, никогда не может быть завершена. Любой результат с момента его получения сразу становится "промежуточным" и требует идти дальше. Только смерть ставит в этом движении окончательное многоточие.

Памятный старый дом в Замоскворечье не сохранился. Москва и наша жизнь изменились. Но неизменно актуальными и увлекательными остаются дела и замыслы Юрия Георгиевича Пузаченко. 